\title{
An audit of bronchoscopy practice in the United Kingdom: a survey of adherence to national guidelines
}

\author{
D Honeybourne, C S Neumann
}

\begin{abstract}
Background - Both patient and staff safety are of major importance during the procedure of fibreoptic bronchoscopy. Patient safety depends partly on adequate disinfection of instruments and accessories used as well as careful monitoring during the procedure. Adequate facilities, manpower and training are also essential. Staff safety depends partly on adequate procedures to minimise any risks of sensitisation to agents such as glutaraldehyde. An audit was carried out of bronchoscopy procedures in hospitals in the UK and the findings were compared with published guidelines on good practice and clinical consensus.
\end{abstract}

Methods - A postal questionnaire was sent to 218 bronchoscopy units in the UK. Findings were then compared with published evidence of good practice in the areas of disinfection, including the use of glutaraldehyde, patient monitoring, manpower, facilities, and training.

Results - A $73 \%$ response rate was obtained. Recommended minimum disinfection times before and after routine bronchoscopies were not achieved by $35 \%$ of units. No disinfection was carried out in $34 \%$ of units before emergency bronchoscopies and in $19 \%$ of units after suspected cases of tuberculosis. Adequate rinsing of the bronchoscope with sterile or filtered water was not carried out by $43 \%$ of units. Contrary to recommendations, $31 \%$ of departments were still using glutaraldehyde in the patient examination room and inadequate room ventilation was common. Protective clothing was often not worn by staff during bronchoscopy. Inadequate intravenous access and use of supplementary oxygen were found in many units. Practice standards were higher in departments where dedicated bronchoscopy/endoscopy units of the hospital were used, and also where staff had been on external training courses.

Conclusions - This audit has shown that many units do not adhere to guidelines on disinfection procedures and patient monitoring. Unnecessary potential risks due to staff exposure to glutaraldehyde were apparent. National guidelines on good practice are not being followed in areas which may potentially affect patient and staff safety. (Thorax 1997;52:709-713)

Keywords: audit, bronchoscopy.
Over the last 15 years fibreoptic bronchoscopy has become a routine procedure in most hospitals in the UK. Guidelines have been published to advise bronchoscopy and endoscopy departments on procedures to minimise the risks to patients and staff. ${ }^{1-6}$ No specific recommendations have been made regarding the site of bronchoscopy, e.g. operating theatre or dedicated endoscopy unit. The term "endoscopy unit" is now widely used where bronchoscopy is carried out in the same area as gastrointestinal endoscopy.

Patient safety during bronchoscopy depends on many factors including adequate cleaning and disinfection of the instruments and accessories, careful monitoring of the patient, and proper training of both the bronchoscopist and also the nurses and ancillary staff. Instrument design has improved progressively over the past few years and most fibreoptic bronchoscopes are now fully immersible which facilitates adequate disinfection. Careful selection of patients for bronchoscopy and adequate monitoring during the procedure are extremely important.

Staff safety partly depends on the use of protective clothing during instrument disinfection. Bronchoscopy staff are also advised to wear gloves, gowns, masks, and close fitting eye protection for all patients since mucocutaneous transmission of HIV has occurred from splashing of blood and secretions ${ }^{7}$ and infective patients cannot always be identified. ${ }^{2}$ Automatic disinfection machines are now available and have the advantage of reducing staff contact with glutaraldehyde.

Both patient and staff safety also depends on adequate manpower, facilities, and training. Training programmes for nurses or technical staff involved with bronchoscopies include individual hospital internal training and external courses which may involve 1-2 days or the English National Board (ENB) 906 three week course.

The aim of this study was to audit bronchoscopy procedures with reference to disinfection, patient monitoring, precautions to prevent unnecessary staff exposure to glutaraldehyde or infection using published national guidelines for comparison.

Methods

A questionnaire was sent to 218 units across the UK known to carry out bronchoscopy in order to evaluate standards of practice. The questionnaire stressed that a single reply was 
Table 1 Details of workload and manpower

\begin{tabular}{lllll}
\hline & $\begin{array}{l}\text { Endoscopy } \\
\text { department } \\
(n=104)\end{array}$ & $\begin{array}{l}\text { Operating } \\
\text { theatre } \\
(n=27)\end{array}$ & $\begin{array}{l}\text { Others } \\
(n=28)\end{array}$ & $\begin{array}{l}\text { Total } \\
(n=159)\end{array}$ \\
\hline $\begin{array}{l}\text { Mean number of bronchoscopies } \\
\text { per year }\end{array}$ & $\begin{array}{l}247 \\
(\text { range }\end{array}$ & $\begin{array}{l}245 \\
\text { (range }\end{array}$ & $\begin{array}{l}254 \\
\text { (range }\end{array}$ & $\begin{array}{l}248 \\
\text { (range }\end{array}$ \\
<2 assisting at a list & $\begin{array}{c}5-800) \\
5(5 \%)\end{array}$ & $\begin{array}{c}50-750) \\
6(22 \%)^{*}\end{array}$ & $\begin{array}{c}40-570) \\
6(21 \%)\end{array}$ & $\left.\begin{array}{c}40-800) \\
17(11 \%)\end{array}\right)$ \\
Emergency out of hours service provided & $66(63 \%)$ & $21(78 \%)$ & $17(61 \%)$ & $104(65 \%)$ \\
\hline
\end{tabular}

$* \mathrm{p}<0.01$.

Table 2 Details of disinfection procedures with non-emergency bronchoscopies

\begin{tabular}{lllll}
\hline & $\begin{array}{l}\text { Endoscopy } \\
\text { department } \\
(n=104)\end{array}$ & $\begin{array}{l}\text { Operating } \\
\text { theatre } \\
(n=27)\end{array}$ & $\begin{array}{l}\text { Others } \\
(n=28)\end{array}$ & $\begin{array}{l}\text { Total } \\
(n=159)\end{array}$ \\
\hline $\begin{array}{l}\text { Minimum 20 min disinfection before } \\
\text { and after each case }\end{array}$ & $74(71 \%)$ & $14(52 \%)$ & $16(57 \%)$ & $104(65 \%)$ \\
$\begin{array}{l}\text { Minimum 60 min after suspected } \\
\text { tuberculosis }\end{array}$ & $93(85 \%) *$ & $16(59 \%) *$ & $20(71 \%)$ & $129(81 \%)$ \\
$\begin{array}{l}\text { Rinsing with sterile or filtered water } \\
\text { after disinfection }\end{array}$ & $62(60 \%)$ & $14(52 \%)$ & $15(54 \%)$ & $91(57 \%)$ \\
\hline$* \mathrm{p}<0.001$. & & & & \\
\hline
\end{tabular}

Table 3 Disinfection facilities

\begin{tabular}{|c|c|c|c|}
\hline & $\begin{array}{l}\text { Departments with } \\
\text { dedicated disinfection } \\
\text { room }\end{array}$ & $\begin{array}{l}\text { Departments with } \\
\text { automated washers/ } \\
\text { disinfectors }\end{array}$ & $\begin{array}{l}\text { Departments with } \\
\text { adequate fume } \\
\text { extractors }\end{array}$ \\
\hline Endoscopy units $(n=104)$ & $79(76 \%)^{*}$ & $90(87 \%)$ & $43(41 \%)$ \\
\hline Operating theatres $(n=27)$ & $16(59 \%)$ & $18(67 \%)$ & $3(11 \%)$ \\
\hline Others $(n=28)$ & $14(50 \%)^{*}$ & $15(54 \%)$ & $11(39 \%)$ \\
\hline Total & $109(69 \%)$ & $123(77 \%)$ & $57(36 \%)$ \\
\hline$* \mathrm{p}<0.02$ & & $\begin{array}{l}\text { Endoscopy units vs } \\
\text { theatres } \mathrm{p}<0.05 \text {. } \\
\text { Endoscopy units vs } \\
\text { others } \mathrm{p}<0.0005 \text {. }\end{array}$ & $\begin{array}{l}\text { Endoscopy units vs } \\
\text { theatres } \mathrm{p}<0.01 \text {. } \\
\text { Theatres vs others } \\
\mathrm{p}<0.05 \text {. }\end{array}$ \\
\hline
\end{tabular}

required from each unit and duplicate replies from the same unit were not counted or analysed. No reminders or repeat mailings were sent. The replies were compared with guidelines on various aspects of fibreoptic bronchoscopy and endoscopy published by the British Thoracic Society, The British Society of Gastroenterology, The Royal College of Surgeons, and "The Control of Substances Hazardous to Health" (COSHH) regulations.

STAFF ISSUES

The questions relating to staff safety covered the following aspects: where bronchoscopy was carried out, which disinfectant was used and which disinfection machines were available, what ventilation system was installed, what protective clothing was worn both during instrument disinfection and bronchoscopy, and what training had staff received. In addition the questionnaire asked whether a separate disinfection room was used, how the accessories were cleaned and what number of staff assisted at bronchoscopy.

\section{PATIENT ISSUES}

The questions relating to patient safety included the number of procedures per year and the number of nurses and/or technicians who assisted with the procedure. Enquiries were made about staff training including resuscitation training. Detailed questions were asked about the precise methods of instrument disinfection both for routine lists and for emergency procedures. Also methods of disinfection for high risk patients (suspected of tuberculosis, HIV infection, hepatitis B or immunosuppression) were requested. The types of premedication and sedation were recorded and whether supplemental oxygen, pulse oximetry, and continuous intravenous access were used.

\section{DATA ANALYSIS}

Statistical analysis of the data was carried out using the Excel ASTUTE scientific and statistical data analysis system. Comparisons of results were performed using the $\chi^{2}$ test with Yates' correction factor or Fisher's exact test where appropriate. A p value of less than 0.05 was considered significant. Analysis of the results was carried out according to the site where bronchoscopies were performed.

\section{Results}

Replies were received from 159 units, a response rate of $73 \%$. Bronchoscopy was carried in a variety of sites. The main bronchoscopy/ endoscopy unit of the hospital was used by $66 \%$ of respondents, the operating theatre by $17 \%$, while the other $17 \%$ used sites such as the thoracic department, dedicated bronchoscopy suites, $x$ ray or outpatient departments or wards. Table 1 shows details of workload, manpower, and the availability of emergency bronchoscopies. Adequate numbers of staff assisting at bronchoscopy were more likely in dedicated endoscopy units.

\section{PATIENT SAFETY}

Table 2 details disinfection procedures for nonemergency bronchoscopies. Performance was significantly better for adequate disinfection after suspected tuberculosis in endoscopy departments than in operating theatres. In addition, of the 104 units that provided an emergency bronchoscopy service, no disinfection prior to bronchoscopy was reported by $34 \%$ and inadequate disinfection after bronchoscopy (less than 20 minutes) by $25 \%$.

Intravenous sedation was used by 112 units (mainly midazolam), opioids by 68 units, and 41 used both. Atropine was used routinely in 109 units $(68.6 \%)$.

\section{STAFF SAFETY}

Table 3 lists how many departments carried out the disinfection process in a dedicated room, the number of departments with automated machines, and the number of departments that had fume extraction appropriate for the type of disinfection facilities and disinfectants used. These facilities were significantly more likely to be available in the endoscopy units than in other departments. The most widely used disinfectant was $2 \%$ activated glutaraldehyde (140 departments) while 11 departments used a formaldehyde based disinfectant and one department used peracidic acid. 
Table 4 Departments with adequate protective clothing worn during instrument disinfection and bronchoscopy

\begin{tabular}{lll}
\hline & $\begin{array}{l}\text { Departments with staff wearing } \\
\text { adequate protective clothing } \\
\text { during disinfection }\end{array}$ & $\begin{array}{l}\text { Departments with staff wearing } \\
\text { full protective clothing }\end{array}$ \\
\hline Endoscopy units $(\mathrm{n}=104)$ & $54(52 \%)^{*}$ & $5(5 \%)^{* *}$ \\
Operating theatres $(\mathrm{n}=27)$ & $8(30 \%)^{*}$ & $5(19 \%)^{* *}$ \\
Others $(\mathrm{n}=28)$ & $12(43 \%)$ & $11(7 \%)$ \\
\hline
\end{tabular}

$* \mathrm{p}<0.05, * * \mathrm{p}<0.02$ bronchoscopy units vs theatres.

Table 5 Effect of training on instrument disinfection

\begin{tabular}{|c|c|c|c|}
\hline & $\begin{array}{l}\text { Routine } \\
\text { OK }\end{array}$ & $\begin{array}{l}\text { Risk } \\
\text { OK }\end{array}$ & $\begin{array}{l}\text { Both } \\
\text { OK }\end{array}$ \\
\hline $\begin{array}{l}\text { In-house only }(n=75) \\
\text { External courses } 1-2 \text { days }(n=60) \\
\text { External courses } 3 \text { weeks }(\text { ENB 906) }(n=24) \\
\text { Total }(n=159)\end{array}$ & $\begin{array}{r}54(72 \%) \\
44(73 \%) \\
20(83 \%) \\
118(74 \%)\end{array}$ & $\begin{array}{l}42(62 \%) \\
33(55 \%) \\
24(100 \%) \\
98(62 \%)\end{array}$ & $\begin{array}{l}27(36 \%) \\
30(50 \%) \\
22(92 \%) \\
79(50 \%)\end{array}$ \\
\hline $\begin{array}{l}\text { ENB vs. others externals } \\
\text { Other externals vs. in-house only } \\
\text { ENB vs. in-house only }\end{array}$ & $\begin{array}{l}\text { NS } \\
\text { NS } \\
\text { NS }\end{array}$ & $\begin{array}{l}p=0.0002 \\
\text { NS } \\
p=0.0002\end{array}$ & $\begin{array}{l}0=0.001 \\
\mathrm{NS} \\
\mathrm{p}<0.0001\end{array}$ \\
\hline
\end{tabular}

Table 4 shows the number of departments that used adequate protective equipment, considering the disinfection equipment and chemicals used, and the number of departments complying with the recommendations regarding protective clothing during bronchoscopy - that is, gloves, gown, mask, and closely fitting eye protection. Performance was again significantly better in endoscopy units. Further analysis revealed that gloves were worn routinely by staff of nearly all departments while only $24 \%$ routinely wore gowns, $27 \%$ face masks, and $21 \%$ goggles. Nearly half of staff working in operating theatres wore gowns and face masks routinely compared with less than a quarter of the others. Close fitting eye protection was not worn routinely by about $20 \%$ of all departments. Even with high risk patients, $28 \%$ of all departments never wore gowns, $16 \%$ never wore face masks, and $19 \%$ never wore goggles.

TRAINING

Of the total of 159 departments $47 \%$ arranged only in-house training, 38\% training at external courses of 1-2 days duration, and $15 \%$ at the three week ENB 906 course. There were no significant differences in these arrangements according to bronchoscopy site (endoscopy unit, operating theatre or others).

Table 5 shows the effect of training courses on disinfection procedures. Further analysis showed that, even within the endoscopy units, those who had staff who had attended the ENB 906 course performed better, especially with regard to disinfection prior to immunosuppressed patients than units with staff who had only attended a 1-2 day course $(\mathrm{p}<0.05)$ or had only had in-house training $(\mathrm{p}<0.002)$. Too few staff at the other sites had attended the ENB 906 to allow for detailed analysis.
Table 6 Effect of training on method of personal protection during disinfection

\begin{tabular}{ll}
\hline & $\begin{array}{l}\text { Adequate } \\
\text { protective } \\
\text { clothing }\end{array}$ \\
\hline In-house only $(\mathrm{n}=75)$ & $23(31 \%)$ \\
External courses $(1-2$ days) $(\mathrm{n}=60)$ & $30(50 \%)$ \\
External courses 3 weeks (ENB 906) $(\mathrm{n}=24)$ & $17(71 \%)$ \\
Total $(\mathrm{n}=159)$ & $70(44 \%)$ \\
\hline $\mathrm{p}=\mathrm{NS}$ ENB vs. 1-2 days external courses.
\end{tabular}

Table 6 reveals the effect of training on the wearing of adequate protective clothing during instrument disinfection.

Resuscitation training for non-medical staff had been given in $93 \%$ of units involved with bronchoscopy. However, $22 \%$ of these units offered no periodic retraining or updating in resuscitation.

\section{Discussion}

This study has highlighted the variety of sites where bronchoscopy is carried out in different hospitals. Two thirds of the 159 responding centres carried out bronchoscopy in the main endoscopy unit of the hospital. The concentration of expertise in such sites may be expected to lead to improved standards of patient safety compared with sites which are not used for bronchoscopy/endoscopy services on a daily basis.

Table 1 shows that the recommended number of at least two nurses or technicians assisting the bronchoscopist was achieved in $95 \%$ of endoscopy units but was lower in the other sites.

\section{PATIENT SAFETY}

Disinfection

Efficient disinfection of the bronchoscope needs to be carried out before and after each patient and this should be for a minimum of 20 minutes when using $2 \%$ glutaraldehyde. ${ }^{1-6}$ The instrument must be scrupulously cleaned manually to remove debris, especially from the channels before being treated with disinfectant. ${ }^{1}$ Inadequate cleaning and disinfection of a suction valve has been reported to have led to cross-infection with Mycobacterium tuberculosis. ${ }^{8}$

Bronchoscopes should be disinfected for 20 minutes before the start of a list ${ }^{1}$ to ensure that any pathogens which have contaminated the bronchoscope in storage such as Pseudomonas aeruginosa have been eradicated. The recommended disinfecting time of 20 minutes after bronchoscopy is thought to be adequate after examining patients who are positive for hepatitis B surface antigen or HIV. ${ }^{910}$ However, after bronchoscopic or endoscopic examination of patients who are suspected of having tuberculosis, a disinfecting time of 60 minutes is recommended. ${ }^{11}$ Before and after examining immunosuppressed patients the disinfection time should be 60 minutes to enable eradication of opportunistic pathogens, especially nontuberculous mycobacteria. ${ }^{4}$ Before and after 
emergency bronchoscopy the instrument should be adequately cleaned and disinfected using the same criteria as for non-emergency cases. Rinsing the bronchoscope after disinfection is important to remove traces of glutaraldehyde but this should be done with sterile or filtered water to avoid the possibility of contamination with opportunistic pathogens especially Mycobacterium chelonei $i^{12-14}$ or $\mathrm{Myco}$ bacterium xenopi. ${ }^{15}$

For routine endoscopy lists dedicated endoscopy units performed significantly better than operating theatres (table 2). The number of units using sterile or filtered water for rinsing was disappointingly low at only $57 \%$ and was very similar to a recent survey. ${ }^{16}$ This obviously raises worries about the risk of introducing opportunistic pathogens into the bronchoscope channels at this stage. An emergency out-ofhours bronchoscopy service was provided by $65 \%$ of units but bronchoscopes received no prior disinfection in $34 \%$ of these units, or inadequate disinfection (less than 20 minutes) before bronchoscopy in $25 \%$ of units. This suggests that specifically trained endoscopy personnel need to be on call.

\section{Sedation and monitoring}

Patients undergoing bronchoscopy may have chronic respiratory disease and sedation used during the procedure is potentially hazardous. Pulse oximetry is recommended during bronchoscopy, as is supplemental oxygen. ${ }^{2}$ Continuous intravenous access should be routinely available if intravenous sedatives are used. ${ }^{23}$ Our survey showed that pulse oximetry was used in $84 \%$ of units. However, supplemental oxygen - which is another recommendation was only routinely practised by $48 \%$ of units. Some respondents did comment, however, that they would use supplemental oxygen for patients at "high risk" or when oxygen saturations fell below $91 \%$. A previous study of bronchoscopic procedures in 1986 showed that only $18 \%$ used routine supplemental oxygen. ${ }^{17}$ Continuous intravenous access was only routinely available in $68 \%$ of units which seems inadequate considering that most departments used intravenous sedatives.

\section{STAFF SAFETY}

Glutaraldehyde risks

Fibreoptic bronchoscopes are heat sensitive and cannot be autoclaved. Disinfection of fibreoptic endoscopes therefore is achieved by chemical means using aldehydes, predominantly $2 \%$ activated glutaraldehyde. Aldehydes can cause sensitisation to both the skin and respiratory tract. ${ }^{1819}$ In the UK surveys have revealed that between $75 \%^{20}$ and $80 \%{ }^{21}$ of endoscopy staff using glutaraldehyde developed symptoms attributed to aldehyde exposure.

Alternatives to aldehyde disinfectants are being investigated. ${ }^{22}$ Aldehydes are substances covered by the Control of Substances Hazardous to Health regulations $(\mathrm{COSHH}){ }^{23}$ Guidelines suggest that departments remove the chemical disinfection process into a dedicated room for this purpose and enclose the disinfection process by using automated washers/disinfectors. ${ }^{24}$ Local exhaust ventilation should be available when using chemicals giving off noxious fumes. ${ }^{23}$ Sterilisation either in the Hospital Sterile Supplies Unit (HSSU) or in bench-top autoclaves has been recommended for endoscope accessories that are compatible with this process, ${ }^{24}$ minimising exposure of staff to the chemicals used in manual disinfection.

Staff safety in the NHS is not only a health concern but also has become of legal importance since the lifting of Crown Immunity for NHS hospitals and the successful prosecution by the Health and Safety Executive of a health authority in $1989 .{ }^{25}$

The full time commitment of staff to procedures in the main endoscopy unit of the hospital may be expected to lead to improved levels of staff training and consequently staff safety compared with sites that do not carry out bronchoscopic/endoscopic procedures on a daily basis. We found that bronchoscopy/ endoscopy units were more likely to use a dedicated disinfection room than other departments (table 3). They were also significantly more likely to use automated disinfection than either the operating theatres or other departments. Full fume extraction within a fume cupboard or with a vapour controlled automated disinfection system was only achieved in just over one third of all departments.

Staff in nearly $60 \%$ of departments did not wear adequate protection during instrument disinfection considering the disinfection facilities available and methods used (table 4). Most departments underestimated the danger of aldehyde vapour with staff not wearing appropriate respiratory protective equipment during chemical disinfection when the disinfection process was not enclosed and the local fume extraction was inadequate. Research is being carried out to assess whether newer agents such as peracidic acid are safe and cost effective alternatives to glutaraldehyde. ${ }^{22}$

\section{Protective clothing}

Apart from wearing protective clothing during instrument disinfection, bronchoscopy staff are also advised to wear gloves, gowns, masks, and close fitting eye protection for all patients since mucocutanous transmission of HIV has occurred from splashing of blood and secretions ${ }^{7}$ and infective patients cannot always be identified. $^{2}$ In addition to closed disinfection systems and fume extraction, employers need to provide and employees need to use protective equipment appropriate for the chemicals used and the facilities available. ${ }^{26}$ Equipment for protection includes nitrile rubber gloves, aprons, chemical grade eye protection, and respiratory protective equipment suitable for removing organic vapour. This study found that staff in only $7 \%$ of departments wore all protective clothing routinely as recommended (table 4). Staff working in operating theatres complied more often than others in the routine 
wearing of masks, gowns and gloves, probably since these are routinely worn for all other procedures. This surprisingly high non-compliance with published guidelines raises the question of whether this was due to lack of knowledge or to the guidelines being impractical to implement. Our study cannot answer this question but it should encourage a review of current guidelines.

\section{Training}

This survey did not ask about details of bronchoscopists' training but only $53 \%$ of units sent their nursing or technical staff on external endoscopy training courses. These external courses varied from one day to three weeks. The beneficial effects of external training of at least one member of staff on the efficiency of disinfection procedures in routine and in high risk cases can be seen in table 5. We cannot answer the question as to whether training of staff on external courses led to more appropriate use of facilities and equipment already present in departments or if the knowledge gained from these courses empowered staff to request better facilities. Either way, training made a positive impact on standards of practice.

The results of this audit suggest that the volume of procedures of various specialities carried out in the main bronchoscopy/endoscopy unit of a hospital has promoted better facilities and equipment for instrument disinfection, potentially making this process less hazardous for staff. Moreover, such departments may have staff better trained in bronchoscopic procedures. Departments with staff committed full time to carrying out these procedures seem to have been on longer training courses and therefore have gained more specialist knowledge. We are, however, concerned that around $50 \%$ of all departments stated that their staff had only received in-house training. It seems unlikely that enough specialised expertise is available in a hospital to train and update staff comprehensively without input from outside sources. This seems to be confirmed by our findings that showed significantly better standards of personal protection and disinfection practice in departments where at least one member of staff had been trained on external courses (table 6).

This survey has revealed that many departments did not apply or follow national guidelines and had inadequate or inappropriate facilities for chemical disinfection. Moreover, staff were often insufficiently trained resulting in inadequate protection from exposure to glu- taraldehyde and from infective organisms from patients. There was evidence that dedicated endoscopy units were more likely to follow national guidelines and had better facilities for chemical disinfection. Training of at least one member of staff on an external training course significantly improved standards of practice.

1 Woodcock A, Campbell I, Collins JVC, Hanson P, Harvey $\mathrm{J}$, Corris $\mathrm{P}$, et al. Bronchoscopy and infection control. Lancet $1989 ; \mathrm{ii}: 270-1$.

2 Harrison BDW. Guidelines for care during bronchoscopy. Thorax 1993;48:584.

3 Royal College of Surgeons of England. Report of the Working Party on Guidelines for Sedation by Non-Anaesthetists, 1993

4 British Society of Gastroenterology. Cleaning and disinfection of equipment for flexible endoscopy: interim recommendations. Gut 1988;29:1134-51

5 Martin MA, Reichelderfer M. APIC guideline for infection prevention and control in flexible endoscopy. Am $\mathcal{F}$ Infect Control 1994;22:19-38.

6 Rutula WA. APIC guidelines for selection and use of disinfectants. Am f Infect Control 1990;18:99-117.

7 Centers for Disease Control. Update: human immunodeficiency virus infections in health-workers exposed
to blood of infected patients. $M M W R$ 1987;36:285-9.

8 Wheeler PW, Lancaster D, Kaiser AB. Bronchopulmonary cross-contamination related to mycobacterial contamination of suction valves of bronchoscopes. F Infect Dis 1989;159:954-8.

9 Kobayaashi H, Tsuzuki M, Koshimizu K, Toyama M, Yoshihara N, Shikata T, et al. Susceptibility of hepatitis B virus to disinfectant or heat. F Clin Microbiol 1984;20:214-6.

10 Spire B, Barre-Sinoussi F, Montagnier L, Chermann JC. Inactivation of lymphadenopathy associated virus by chemical disinfectants. Lancet 1984;ii:899-901.

11 Ayliffe GAJ, Babb JR, Bradley CR. Disinfection of endoscopes. J Hosp Infect 1986;7:296-9.

12 Nye K, Chadha DK, Hodgkin P, Bradley C, Hancox J, Wise R. Mycobacterium chelonei isolation from bronchoalveolar lavage fluid and its practical implication. $\mathcal{F}$ Hosp Infect 1990;16:257-61.

13 Wang H-C, Liaw Y-S, Yang P-C, Kuo S-H, Luh K-T. A pseudoepidemic of Mycobacterium chelonei infection caused
by contamination of a fibreoptic bronchoscope suction channel. Eur Respir 7 1995;8:1259-62.

14 Brown NM, Hellyar EA, Harvey JE, Reeves DS. Mycobacterial contamination of fibreoptic bronchoscopes. Thorax 1993;48:1283-5.

15 Bennett SN, Peterson DE, Johnson DR, Hall WN, Robinson-Dunn B, Dietrich S. Bronchoscopy-associated
Mycobacterium xenopi pseudoinfections. Am 尹 Respir Crit Mycobacterium xenopi pseud

16 Uttley AHC, Simpson RA. Audit of bronchoscope disinfection: a survey of procedures in England and Wales and incidents of mycobacterial contamination. F Hosp Infect 1994;26:301-8.

17 Simpson FG, Arnold AG, Purvis A, Belfield PW, Muers MF, Cooke NJ. Postal survey of bronchoscopic practice by physicians in the United Kingdom. Thorax 1986;41: $311-7$

18 Norbäck D. Skin and respiratory symptoms from exposure to alkaline glutaraldehyde in medical services. Scand $f$ Work Environ Health 1988;14:366-71.

19 Corrado OJ, Osman J, Davies RJ. Asthma and rhinitis after exposure to glutaraldehyde in endoscopy units. Hum Toxicol 1986;5:325-7.

20 Neumann C.S. Chemical instrument disinfection: a hazard to hospital staff? Thesis CNAA. Postgraduate Diploma in Research Methodology, Birmingham Polytechnic, 1990.

21 McAdam JG, Leicester RJ. Incidence of aldehyde sensitivity in endoscopy units. Gut 1992;33:S52.

22 Fraise A. Disinfection in endoscopy. Lancet 1995;346:787-8.

23 Control of Substances Hazardous to Health Regulations $(\mathrm{COSHH})$. Approved code of practice control of substances hazardous to health and approved code of practice control of carcinogenic substances. London: HMSO 1988

24 Cowan RE, Manning AP, Ayliffe GAJ, Axon ATR, Causton JS, Cripps NF, et al. Aldehyde disinfectants and health in endoscopy units. Report of a British Society of Gastroenterology Working Party. Gut 1993;34:1641-5.

$25 £ 1000$ fine in toxic fumes case. The Times 22 August 1989

26 Department of Health. Glutaraldehyde disinfectants: use and management. Safety Action Bulletin 1992;17. 